\title{
Theoretical and Methodical Basis for Audit Activity Standardization
}

\section{Ekaterina Valerievna Lariunina ${ }^{1}$}

\author{
Ilya Anatolievich Slobodnyak² \\ ${ }^{1}$ Department of Finance and Accounting, Irkutsk State Transport University, Irkutsk, Russian Federation \\ 2Department of Accounting and Audit, Baikal National University of Economics and Law, Irkutsk, Russian Federation
}

Doi:10.5901/mjss.2015.v6n4s4p266

\section{Abstract}

One of the problems of performing audit activity is development of methodology basis for the development of audit activity standards. This work proposes the principles of audit activity standardization divided into three groups: principles determining theoretic basis for audit activity standardization; principles determining the procedure for development of audit activity standards; principles determining the content of audit activity standards. The number of audit activity principles is expanded through adding such principles as principle of scientific approach, system approach, reflection, advanced development, rationality, coordination, independence, conformity to plan, feedback, innovative activity, publicity, timeliness, technology application, neutrality, and ability to check compliance with a standard. The conclusion was made that meeting the proposed principles will allow to improve the quality of services provided by auditing organizations and individual auditors. Methods applicable for audit activity standardization were considered. It was determined that practical methods and special standardization methods allow to fully meet all the proposed principles of audit activity standardization. Objects of audit activity standardization were identified: services provided by auditing organizations and individual auditors and processes of providing those services. The following groups of standards were proposed: standards of services, standards of providing services, and standards of infrastructure for providing services. An audit activity standard was defined. A system of indicators evaluating compliance with the principles of audit activity standardization was developed. Two types of evaluation were proposed: rapid evaluation of compliance with the principles of audit activity standardization in the form of testing and detailed evaluation of compliance with the principles of audit activity standardization. The two types of evaluation can serve as criteria for evaluation of the quality of audit activity standards.

Keywords: audit activity, audit activity standardization, audit activity standards, classification of audit activity principles, objects of audit activity standardization, methods of audit activity standardization, indicators evaluating compliance with the audit activity principles.

\section{Introduction}

\subsection{Introduction of the Problem}

It is common knowledge that audit activity standards create the required prerequisites for achieving a certain level of audit services. Compliance with the standards allows to optimize costs of providing audit services. Using the standards improves mutual understanding between auditors and clients. At present, however, audit activity standards are developed mainly through generalization of experience in performing audits, while theoretic basis for audit activity standardization is usually limited to classifications of audit activity standards and issues of compliance with the system of international audit standards.

\subsection{Importance of the Problem}

Although audit activity standardization has been implemented in Russia for more than twenty years now, its methodological basis and methodical propositions remain underdeveloped, which shows in the lack of uniform approaches to development of audit activity standards of different levels, lack of a single structure among standards, and different styles of presenting information. All that makes it much more difficult to study the principles in practice, understand individual propositions, and makes working with standards unergonomic. For example, principles and methods of audit activity standardization are understudied and there is no precise classification of the objects of audit activity standardization. In addition, there are no uniform methodical approaches to development of audit activity 
standards. At present, every subject of standardization independently establishes the procedure for development and review of audit activity standards, which results in non-compliance between standards of different levels. Moreover, there is a lack of a procedure for estimating the quality of audit activity standards. In this connection, study of methodology basis for audit activity standardization is considered relevant, because development of methodology basis for audit activity standardization will allow to eradicate the deficiencies mentioned above.

The goal of this research is to develop methodology for audit activity standardization. To achieve the goal of the research, the following tasks were set:

- specify the set of principles of audit activity standardization;

- identify the objects of audit activity standardization, specify the definition of audit services, and expand the classification of audit services;

- study the set of methods which secure adherence to the author's system of principles of audit activity standardization;

- propose the author's definition for audit activity standard and add new classification criteria to the classification of audit activity standards;

- develop methods for evaluation of compliance with the principles of audit activity standardization.

\subsection{Relevant Scholarship}

The concept of audit activity and its fundamental principles were coined and elaborately developed by both foreign and Russian researchers. A significant contribution to the development of theoretical basis of audit activity was made by such scholars, as A. Arens, R.P. Bulyga, S.M. Bychkova, M.A. Gorodilov, E.M. Guttsait, U.A. Danilevskiy, F.A. Delfiz, D.R. Carmichael, J. Lobbeck, V.I. Podolskiy, J. Robertson, Y.V. Sokolov, S.M. Shapiguzov, V.T. Chaya, A.D. Sheremet, etc.

The authors studying audit activity standartization used the scientific basis from the works by V.Y. Belobragin, Y.N. Bernovskiy, B. Z. Brod, G.P. Bunin, M.A. Nikolaeva, V.M. Postyko, etc.

Conceptual basis for audit has been studied in a great number of works. However, those works ignored the issues surrounding audit activity standardization and development of the mechanism for improving the standards of providing audit services. All that affects negatively the quality and, therefore, practical application of audit activity principles.

\subsection{Hypotheses and Their Correspondence to Research Design}

The authors make the following assumption: although every audit activity standard is unique, they must be developed on a single basis which would provide high quality of the standards.

\section{Method}

The following methods were applied during the research: methods of system, comparative, and historical analysis, synthesis, induction, deduction, scientific generalization, etc.

The information basis for the research comprised legislative and statutory acts of the Russian Federation, which regulate the issues of standardization and procedure for audit activity, international audit standards, scientific papers and monographs on the studied topic.

\section{Results and Discussion}

Audit activity standardization is built on the principles forming its basis. Unlike the principles of audit activity standardization mentioned in the works by E.M. Guttsait (Guttsait, 2002), S.I. Zhminko and P.V. Baklanova (Zhminko and Baklanova, 2012), B.T. Zharylgasova (Zharylgasova, 2007), and V.I. Podolskiy (Podolskiy, 2010), the authors specified and expanded them by adding such principles as principle of scientific approach, system approach, reflection, advanced development, rationality, coordination, independence, conformity to plan, feedback, innovative activity, publicity, timeliness, technology application, neutrality, and ability to check compliance with a standard. Based on the conducted research, the authors proposed a system of principles of audit activity standardization. The principles of audit activity standardization are divided into three groups: principles determining the theoretical basis for audit activity standardization; principles determining the procedure for development of audit activity standards; and principles determining the content of audit activity standards (Table 1). 
Table 1 - Principles of audit activity standardization

\begin{tabular}{|l|l|l|}
\hline $\begin{array}{l}\text { Principles determining theoretic base for } \\
\text { audit activity standardization }\end{array}$ & $\begin{array}{l}\text { Principles determining the procedure for } \\
\text { development of audit activity standards }\end{array}$ & $\begin{array}{l}\text { Principles determining the content of audit activity } \\
\text { standards }\end{array}$ \\
\hline Principle of system approach & Principle of purposefulness & Principle of consistency \\
\hline Principle of scientific approach & Principle of coordination & Principle of compliance with international standards \\
\hline Principle of reflexion & Principle of independence & Principle of neutrality \\
\hline Principle of advanced development & Principle of conformity to plan & Principle of applicability \\
\hline Principle of rationality & Principle of feedback & Principle of relevance \\
\hline & Principle of competence & $\begin{array}{l}\text { Principle of ability to check adherence to standard } \\
\text { requirements }\end{array}$ \\
\hline & Principle of team work & Principle of target orientation \\
\hline & Principle of innovative activity & Principle of significance \\
\hline & Principle of publicity & Principle of conciseness \\
\hline & Principle of timeliness & Principle of completeness \\
\hline & Principle of technology application & Principle of understandability \\
\hline & & Principle of sequence \\
\hline
\end{tabular}

All the above-mentioned principles are interdependent, both within the same group and across different groups. For example, organization and operation of the system of audit activity standardization is strongly determined by the goals which must be achieved in the result of those processes. Compliance with the principle of purposefulness determines the sense of operation of the system. The goals of audit activity standardization must be set in accordance with the principle of innovative activity, principle of timeliness, principle of independence, principle of conformity to plan, and principle of feedback. The principle of independence allows to set objective and independent goals of audit activity standardization. At the stage of setting goals, the principle of innovative activity contributes to the progress of development of standards. The principle of feedback determines relevance of the goals set and their compliance with the needs of users of the standards. Following the principle of conformity to plan secures rational achievement of the goals of audit activity standardization, while the principle of timeliness secures their real nature and feasibility.

Relationships between the principles of advanced development, innovative activity, and relevance can serve as examples of intergroup relationships. Only compliance with the principle of advanced development, i.e. when the development of theoretical aspect of audit activity standardization outstrips its practical aspect, makes it possible to follow the principle of innovative activity. Otherwise, there will be the lack of innovations needed for practical aspects of development of audit activity standards. Compliance with the principles of advanced development and innovative activity allows to follow the principle of relevance as well, because when determining relevance of an audit activity standard one takes into account, among other things, how much it complies with the current level of scientific development.

That set of principles has a new property which every individual principle lacks - the ability to provide high quality of audit activity standards. This calls for a conclusion that the proposed system of principles of audit activity standardization follows the principle of emergence,i.e. non-equality to the sum of properties of the system's elements.

The proposed system of principles of audit activity standardization can serve as a criterion for evaluation of quality of audit activity standards as a final result of audit activity standardization. Quality standards of audit activity determine the quality of services provided by audit organizations and individual auditors. For this reason, only simultaneous adherence to all the proposed principles advances the achievement of such a goal of audit activity standardization, as providing high quality and competitiveness of services provided by audit organizations and individual auditors.

The conducted analysis allows to state that only simultaneous application of the general scientific methods applied in practice and special methods of general theory of standardization will allow to implement the whole set of principles of audit activity standardization. Those methods include:

- theoretical methods (analysis, synthesis, abstracting, specification, generalization, formalization, induction, deduction);

- empirical methods (studying relevant literature, documents, results of performance, observation, measurement, survey, expert evaluation, testing, object watching, inspection, monitoring, study and generalization of experience, experiments) (Novikov, Novikov, 2007);

- special methods of standardization (unification, ranging, selection, simplification, typification, classification, methods of terminology, parametric rows, general technical requirements, general technical conditions, method of typical service) (Belobragin, 2011).

To our opinion, unification deserves special attention. Unification is a method based on selecting the optimal number of objects of standardization or their sizes, in order to convert them to a single system, form, i.e. to uniformity 
(Nikolaeva, Kartashova, 2010). V.T. Chaya emphasizes the importance of establishing a unified system of documents and requirements for the external check of quality of performance of auditing organizations (Chaya, 2012). Y.Y. Kostyleva and V.A. Kostylev emphasize the importance of unifying audit documents, including a report on the results of an audit check (Kostyleva, Kostylev, 2005). Besides the process of control of quality of provided services, a unified documentation procedure is needed for other processes, such as planning of the procedure for providing a service, providing a service, and preparation of final documents.

Unification of terms used in professional audit standards is also important. Analysis of regulations performed by V.F. Massarygina demonstrates that one and the same term is defined differently in different documents (Massarygina, 2012).

The role of an object of standardization can be performed by everything that can be used multiple times (Burtsev, 2000). In this connection, according to the analysis of approaches to identifying objects of standardization by V.M. Postyka and V.V. Philippov (Postyka and Philippov 2012), M.A. Nikolaeva and L.V. Kartashova (Nikolaeva, Kartashova, 2010), V.Y. Belobragyn (Belobragyn, 2011), Y.N. Bernovskiy (Bernovskiy, 2012), objects of audit activity standardization include services provided by audit organizations and individual auditors and processes of providing repetitive services.

There is a lack of a single classification of services which can be provided by audit organizations and individual auditors. According to M.V. Chernova, the current notion of "audit" goes beyond financial aspects. Audit has taken new forms and started to develop in multiple directions (Chernova, 2011). There is financial audit and such types of "audit", as ecological audit, production audit, operating audit, as well management audit, performance audit, constitution audit, etc. (Sheremet, 2007).

Along with M.V. Chernova, expansion of areas of audit application and new forms of audit are mentioned in the works by R.P. Bulyga (Bulyga, 2012), M.V. Melnik, and V.G. Kogdenko (Melnik, Kogdenko, 2005), S.V. Pankova, and L.V. Pasechnikova (Pankova, Pasechnikova, 2013). One can hardly deny that fact, because it is an objective reflection of the current state of the audit services market.

In academic literature, specialists also failed to come to a single opinion about the legitimacy of providing audit services by audit organizations and individual auditors. While some authors think that extra services provided by subjects of audit activity must not go beyond providing accounting services and tax consultations, others propose to reduce the range of those services within further improvement of legislation by excluding training, evaluation activity, and other services, others suggest establishing an exhaustive list of services relating to compulsory audit, others insists on raising almost all limitations on audit-relating services (Zevaikina, 2010). For example, V.I. Petrova notes that audit-related services include all other services which audit organizations are permitted to provide by law (Petrova, 2009).

According to E.M. Guttsait, the issue of establishing a register and regulation of audit-related services must be addressed by using a deductive method, which means that a definition must be introduced which would allow to decide whether that permission covers each area of activity (Guttsait, 2002). A.D. Sheremet also emphasizes the importance of that issue: "there is an obvious need for a scientific interpretation of audit, audit-related services, and their classification" (Sheremet, 2007). I.B. Shurchkova also points out that the lack of definitions of audit-related and other services makes it difficult to identify some areas of activity (Shurchkova, 2012).

It cannot be denied that the lack of such a definition makes differentiation between audit-related services and other services difficult. Moreover, this allows to include any service into that group, if the relevant standard is developed.

To our opinion, audit checks should be understood as checks, the purpose of which is to confirm compliance of the studied subject with the set criteria. When providing audit services, the subject of study may be both financial and nonfinancial information about all types of resources, the proper use of which must be confirmed. Table 2 shows the classification of audit services.

Table 2 - Classification of audit services

Nature of the information, accuracy of which is confirmed by the auditor Audit services confirming accuracy of financial information

Audit services confirming accuracy of non-financial information
Classification criterion Subject of study, in relation to which compliance Level of certainty achieved by Information serving as criteria, with criteria is confirmed auditor when providing the

Audit services confirming accuracy of information about operation of organization systems and processes

Audit services confirming accuracy of information about the use of technical charactistics of the resources used Audit services confirming accuracy of information about the use of labor forces services Audit services providing reasonable level of certainty by audito Audit services confirming compliance with general criteria

Audit services providing limited Audit criteria confirming level of certainty compliance with local criteria 
When performing audit, the auditor must reach a reasonable level of certainty, while when performing reviews the level of certainty must be limited. That approach will also allow to combine all the existing types of audit.

Audit-related services are services which do not give the auditor any certainty regarding the accuracy of information.

The identified objects imply identification of the following groups of standards:

- standards of services (standards describing the result of providing audit services and audit-related services);

- standards of providing services (standards of processes of providing audit and audit-related services);

- standards of infrastructure for providing services (standards of conditions needed to provide audit and auditrelated services and to achieve the final result).

Under a standard of audit activity one should understand a document, which contains compulsory and repeatedly used rules for providing audit and audit-related services. That definition expands the circle of potential developers of standards. Compulsory use of standards is a necessary condition for securing uniformity of audit activity. The definition points out providing audit and audit-related services as an area of application of standards.

Orientation of the standards must be taken into account as well. For example, the standards of services must be oriented mainly at clients; the standards from the second group- at providers of services, and the standards from the third group - at supervising agencies which supervise the procedure for providing services.

Each of the three groups of standards has its internal classification, which depends on the needs of main users of a given group of documents. Lack of standards from one of the groups endangers providing high-quality services and compliance with the principles of audit activity standardization. Each group of the proposed standards implements the relevant group of principles. The relationship between groups of standards and group of principles is shown in Table 3.

Table 3 - Relationship between standards and implemented principles of audit activity standardization

Group of standards

Standards of services

Standards of providing services

Standards of infrastructure for providing services
Groups of principles implemented

Principles forming the basis for audit activity standardization Principles determining the content of standards of audit activity

Principles determining the procedure for development of audit activity standards

Lack of evaluation of compliance with the principles of audit activity standardization, which must form the basis for the process of audit activity standardization and can serve as evaluation criteria for quality of audit activity, makes it difficult to develop necessary measures aimed at improvement of audit activity standardization.

It should be noted that evaluation of compliance with the principles is necessary for determining the level of their observation, because a principle of audit activity standardization may be followed to completely or partially, or not followed at all, and for development of the necessary measures aimed at improvement of the procedure for development and review of audit activity standards. The extent of compliance with the principles of audit activity standardization depends on the indicators used for evaluation.

Evaluation of compliance with the principles of audit activity standardization must be performed in accordance with certain principles, e.g. the principles of evaluation proposed by E.M. Korotkov. They include:

- principle of scientific approach. Evaluation must be performed by using scientifically grounded methods.

- principle of purposefulness. Evaluation must be aimed at a specific goal.

- principle of diversity, completeness, and consistency. When performing an evaluation, one should take into account relationships between characteristics of the object of evaluation, aspiration to their completeness, diversity, and sufficiency.

- $\quad$ principle of criterion rigidity. When performing an evaluation, optional change of criterion is inadmissable.

- principle of quantity determination of an evaluation. An evaluation must be performed in quantity indicators, whenever possible.

- principle of combining evaluation of state and alterations.

- principle of independence. Evaluation must be isolated from the influence of interested parties (Korotkov, 2000).

In our opinion, the list of principles identified by E.M. Korotkov is sufficient for performing an evaluation of compliance with the principles of audit activity standardization.

Depending on the goal, one can differentiate between rapid and detailed evaluation of compliance with the principles of audit activity standardization. Table 4 contains comparative analysis of the two types of evaluation. 
Table 4 - Comparative analysis of evaluations of compliance with the principles of audit activity standardization

\author{
Comparative criterion \\ Nature of the studied issue \\ Goal of using the results of \\ evaluation \\ Users of evaluation results \\ Nature of source data \\ Availability of source data \\ Evaluation costs \\ Duration of estimating \\ Form of evaluation
}

Rapid evaluation

Determination of compliance or non-compliance

with the principles of audit activity standardization

Determine the quality of audit activity

All interested parties
Public information
Public information
insignificant
insignificant
Test questions

\section{Detailed evaluation}

Determination of effectiveness of using the methods securing

compliance with the principles

Identify effective methods securing compliance with the principles of

audit activity standardization and develop additional methods, if the

existing methods are not enough

Developers of audit activity standards

Insider information

Special information basis is needed

significant

significant

Calculation of quantity indicators

Indicator is a means of evaluation. Indicators help judge about the development or progress of something (Ozhegov, 1987). Indicators must meet certain requirements. In our opinion, the following requirements proposed by E.M. Korotkov can be used as requirements for indicators of compliance with the principles of audit activity standardization:

- validity - indicator must comply with the goals for which it is used;

- dimensions - indicator must not combine factors of different dimensions;

- measurability - indicator must be quantity-measurable or have a word form (increase, more, less, admissible, positive tendency, reasonable, etc.);

- fact basis - indicator must rely on facts;

- reasonable simplicity - if possible, indicator must be simple in structure, calculations, conditions of use, and structure of information;

- function determination - indicator must have its own function (aggregation of information, means of analysis, motivation, control, regulation leverages, etc.);

- consistency - indicators must be compatible and interdependent, meet the integrating purpose, rule out duplication and unjustified overlapping;

- $\quad$ orientation at practical use - indicators must be applicable in practice (Korotkov, 2000).

Every type of evaluation has its own indicators. As the principles of audit activity standartization are interrelated and the principles determining the procedure for audit activity standartization and the content of standards are built on the principles determining the theoretical basis, we think that it will suffice to develop indicators for those two groups of principles only.

In our opinion, rapid evaluation of compliance with the principles of audit activity standartization can be performed in the form of testing. Table 5 shows the indicators used for rapid evaluation of compliance with the principles of audit activity standardization.

Table 5 - Indicators of rapid evaluation of compliance with the principles of audit activity standardization

Principle, compliance with which is Indicator estimated through the indicator

Principle of purposefulness

Principle of independence

Principle of coordination

Principle of conformity to plan

Principle of feedback

Principle of competence

Principle of team work

Principle of innovative activity

Principle of publicity

Principle of timeliness
The principles determining the procedure for the development of standards Are the goals of development of audit activity standards known to all the interested parties? Are development and approval of audit activity standards performed by the authorized agency?

Is there a procedure for development and approval of audit activity standards which contains functional obligations of every subject participating in the standardization process?

Is there a program for development of audit activity standards complying with the goals of development of those standards?

Are there tools to collect information about the problems of practical application of audit activity standards?

Do the developers of audit activity standards have documents confirming their education in a relevant field, experience, and reputation?

Are audit activity standards developed and discussed by a group of people?

Does the text of an audit activity standards or the notes to it contain references to scientific articles used for its development?

Is information about the applicable audit activity standards, procedure for their development, current work on development of standards, and monitoring of execution of plan of standards development pubic?

Is the limited interval between identification of the need to develop an audit activity standards

Variants of answer

yes

yes

yes

yes

yes

yes

yes

yes

yes

yes no no no no no no no no no no 
and its introduction not exceeded?

Principle of technology application Does the development of audit activity standards require extra technical resources?

Principle of consistency Principle of compliance with international standards s Principle of neutrality Do audit activity standards undergo a legal expertise?

Are there unjustified discrepancies in the texts of audit activity standards and international audit standards?

Do representatives of groups with different interests (audited entities, auditors, clients, state agencies, investors, creditors, researchers) participate in development and discussion of audit activity standards?

Principle of applicability Principle of relevance Principle of ability to check adherence to standard requirements

Principle of target orientation

Principle of significance

Principle of conciseness Principle of completeness

Principle of understandability Principle of sequence Principle of single structure Total number of "Yes"/"No" answers
Are audit activity standards reviewed on a regular basis?

Does the text of an audit activity standard contain indicators of compliance with every standard requirement?

Does the introductory part of the audit activity standard contain a certain group of users of that standard?

Does all the information containing in the texts of audit activity standards affect the decisions made by the users of that information?

Do the texts of audit activity standards contain unused clauses?

Do audit activity standards contain all the necessary information so that methodical guidance on their application is not needed?

Do audit activity standards undergo a linguistic expertise?

Are the main provisions of an audit activity standard structured as sections of a document? Do audit activity standards have a single structure?

\begin{tabular}{|c|c|}
\hline yes & no \\
\hline yes & no \\
\hline yes & no \\
\hline ves & no \\
\hline yes & no \\
\hline & no \\
\hline
\end{tabular}

yes no

yes no

yes no

yes no

yes no

yes no

yes no

"Note-"yes" is worth 1 point, "no" is worth 0 point

The maximum number of points totals 24 . The higher the number of "yes" answers, the more principles are met and the higher is the quality of standards.

When using the indicators of rapid evaluation, one should bear in mind that they are "rigid" and imply only two variants of compliance with the standardization principles: the principle is complied with or not. The results of the rapid evaluation do not allow to identify reasons for non-compliance with a given principle and depend on the opinion of the expert performing the evaluation. Despite those deficiencies, the results of rapid evaluation allow to identify weak spots regarding compliance with the principles of audit activity standardization and form the basis for development of a plan of measures aimed at eradicating the deficiencies identified in audit activity standardization.

Detailed evaluation allows to identify the need to develop the tools which would secure compliance or enhance compliance with the principles which were not met or undermet. Table 6 shows the absolute and relative indicators of detailed evaluation of compliance with the principles of audit activity standardization.

Table 6 - Indicators of detailed evaluation of compliance with the principles of audit activity standardization

Principle

Principles determining the procedure for development of standards

Principle of purposefulness $\quad$ - number of standards meeting the needs of their users;

Principle of independence

Principle of coordination

Principle of conformity to plan

Principle of feedback
- number of standards, development of which is funded not by their developer;

- number of identified cases of non-compliance with the procedure or functional obligations;

- amount of costs for elimination of the effects of breaking the regulations;

- amount of time needed to provide information to the recipient:

- number of cases of losing information;

- number of standards meeting the goals of standardization;

- number of planned standards developed;

- number of unplanned standards developed;

- number of planned reviews of standards;

- number of unplanned reviews of standards;

- number of proposals made regarding program development;
Relative

- share of standards meeting the needs of their users in the total number of standards;

- share of standards, development of which is funded not by their developer, in the total number of standards;

- number of standards developed per unit of time;

- number of standards per 100 thousand rubles spent on

development and approval of standards;

- average amount of costs for elimination of one noncompliance with the regulations;

- share of planned standards developed in the total number of developed standards;

- share of planned developed standards in the total number of standards planned to be developed;

- share of planned reviews of standards on the total number of reviewed standards;

- share of planned reviews of standards in the total amount of standards planned to be reviewed;

- share of approved changes in the total number of proposals made on program development; 


\begin{tabular}{|c|c|c|}
\hline & $\begin{array}{l}\text { - number of presented projects of the standard; } \\
\text { - number of comments on the project of a standard; } \\
\text { - number of cases when a standard needed correction } \\
\text { work; }\end{array}$ & $\begin{array}{l}\text { - share of approved changes in the total number of proposals on } \\
\text { standard development; } \\
\text { - average number of comments on the project of a standard; } \\
\text { - average number of projects of standards; }\end{array}$ \\
\hline Principle of competence & $\begin{array}{l}\text { - number of people, which completely comply with the } \\
\text { indicators forming the basis for rating evaluation; }\end{array}$ & $\begin{array}{l}\text { - number of standards per one developer; } \\
\text { - average rating of the developer based on the system of } \\
\text { indicators; }\end{array}$ \\
\hline Principle of team work & $\begin{array}{l}\text { - number of people participating in development and } \\
\text { approval of standards; } \\
\text { - voting results; }\end{array}$ & - share of "pro" votes in the total number of votes; \\
\hline Principle of innovative activity & $\begin{array}{l}\text { - number of key innovations; } \\
\text { - number of researchers participating in the development } \\
\text { of the standard; } \\
\text { - number of references to scientific articles used for } \\
\text { standard development in the notes to the standard; } \\
\text { - number of standards developed by research institutes; }\end{array}$ & $\begin{array}{l}\text { - share of key innovations in the total number of changes to the } \\
\text { standard; } \\
\text { - share of researchers participating in standard development, in } \\
\text { the total number of developers; } \\
\text { - share of standards developed by research institutes in the total } \\
\text { number of developed standards; } \\
\text { - average number of proposed innovative changes; }\end{array}$ \\
\hline Principle of publicity & $\begin{array}{l}\text { - number of requests on providing information which is } \\
\text { supposed to be public; } \\
\text { - number of cases when the procedure for sharing } \\
\text { compulsory information with users was broken; } \\
\text { - amount of time spent on searching for the necessary } \\
\text { information; } \\
\text { - amount of time between approving the standard and } \\
\text { informing the user about it; }\end{array}$ & $\begin{array}{l}\text { - share of requests on providing information in the total number } \\
\text { of requests; } \\
\text { - average amount of time spent on searching for the necessary } \\
\text { information; }\end{array}$ \\
\hline Principle of timeliness & $\begin{array}{l}\text { - amount of time between identification of the need for } \\
\text { standard development and its introduction; } \\
\text {-number of applications for explanation regarding } \\
\text { application of provisions of the standard under uncertainty }\end{array}$ & $\begin{array}{l}\text { - time needed to eliminate contradictions and to make additions } \\
\text { to the standard; } \\
\text { - average time needed to eliminate contradictions and to make } \\
\text { additions to the standard; }\end{array}$ \\
\hline $\begin{array}{l}\text { Principle of technology } \\
\text { application }\end{array}$ & - costs for organizing audit activity standardization; & $\begin{array}{l}\text { - average costs for development and introduction of one } \\
\text { standard; }\end{array}$ \\
\hline
\end{tabular}

Principle determining the content of standards

Principle of consistency - number of times contradictions were identified in the texts of standards at the development stage; - number of times contradictions were identified in the texts of standards at the application stage; - number of contradictory court judgments under the same circumstances;

Principle of compliance with - number of contradictions between the standards and international standards IAS;

- number of justified contradictions

- number of eliminated contradictions;

- number of non-eliminated contradictions -number of standards, which comply with IAS;
Principle of neutrality

Principle of applicability

Principle of relevance

Principle of ability to check fulfillment of requirements set forth in the standard
- number of representatives of different groups (clients, audited entities, auditors, state agencies, investors, creditors, researchers), participating in development and discussion of standards;

- number of law suits on infringement of rights and lawful interests of the participants of audit activity due to compliance with the requirements of the standard; - number of additions made to the standard;

- number of times users asked for explanations regarding application of standard's provisions;

- number of references to the text of the standard; - number of times when auditor's documents lacked references to the provisions of the standard; - number of changes made to the standard;

- number of indicators of fulfillment (non-fulfillment) of standard's provisions regarding every requirement set forth in its text;

- number of standards, for which it is possible to check
- share of standards, the texts of which do not contradict other documents, in the total number of standards; - average number of contradictions per one standard;

- share of justified contradictions between the developed and international standards in the total number of contradictions of that kind;

- share of eliminated contradictions between the developed and international standards in the total number of contradictions of that kind;

- share of non-eliminated contradictions between the developed and international standards in the total number of contradictions of that kind;

- share of standards which fully comply with international standards, in the total number of standards;

- average number of contradictions between the developed and international standards per one standard;

- share of each group of representatives (clients, audited entities, auditors, state agencies, investors, creditors,

researchers), participating in development and discussion of standards in the total number of participants;

- share of law suits, where infringement of rights was adjudged, in the total number of law suits of that kind;

- share of applications for explanation regarding application of provisions of the standard, in the total number of applications; - average frequency of review of the content of standards;

- frequency of review of the contents of the standard;

- share of non-used standards in the total number of standards; - average frequency of review of contents of the standard;

- share of requirements with no indicators of their fulfillment, in the total number of requirements set forth in the standard; - share of standards with requirements, fulfillment of which is impossible to check, in the total number of standards; 


$\begin{array}{ll} & \text { fulfillment of each requirement; } \\ \text { Principle of target orientation } & \text { - number of standards, in which the recipient is not } \\ & \text { identified; } \\ \text { Principle of significance } & \text { - number of applications for explanation regarding } \\ & \text { application of provisions of the standard; } \\ & \text { - amount of time spent on decision-making under } \\ & \text { uncertainty; } \\ & \text { - size of a fine for non-fulfillment of requirements set forth } \\ & \text { in the standard; } \\ \text { Principle of conciseness } & \text { - number of unused standards; } \\ & \text { - number of unused provisions of standards; }\end{array}$

Principle of completeness

Principle of understandability

Principle of sequence

Principle of single structure application of provisions of the standard; - amount of time spent on decision-making under uncertainty;

- number of applications for explanation regarding application of provisions of the standard; provisions:

- number of contradictions identified in the standards; - number of applications for explanation regarding application of provisions of the standard;
- average number of requirements set forth in the standard with no indicators of their fulfillment, per one standard;

- share of standards, in which the recipient is not identified, in the total number of standards;

- share of applications for explanation regarding application of provisions of the standard, in the total number of applications;

- average time spent on making one decision under uncertainty;

- share of unused standards in the total number of standards - share of unused provisions of standards in the total number of provisions of standards;

- average number of unused provisions in one standard; - share of applications for explanation regarding application of provisions of the standard, in the total number of applications; - average time spent on making one decision under uncertainty; - number of changes made to the standard to specify its

- share of applications for explanation regarding application of provisions of the standard, in the total number of applications; - average number of applications for explanation regarding application of provisions of the standard;

- share of applications for explanation regarding application of provisions of the standard, in the total number of applications; - average number of applications for explanation regarding application of provisions of the standard;

- number of standards with the structure different from the - share of standards with the structure different from the generally established one;

The indicators from Table 6 allow to estimate the state of the system of principles of audit activity standardization. As the relative indicators of detailed evaluation may vary from 0 to 1 , it is not quite right to say that the principle is complied or not complied with completely: the principle is complied with partially. Values of those indicators can give information about support of functions securing compliance with the principles, authorities, technical tools, etc.

In addition, there is a need for indicators which would reflect changes taking place in the system of principles of audit activity standardization. Those are indicators of dynamics which show growth of characteristics, expansion of their area of application, new options of using resources, and anything that characterizes a new quality. Those indicators include:

- relative indicator of dynamics defined as a ratio of current indicator to indicator in previous (basis) period;

- relative indicator of plan fulfillment defined as a ratio of planned value of the indicator over period $i$ to the its actual value over period $i$.

- In our opinion, to improve effectiveness of work on compliance with the principles of audit activity standardization, the indicators of compliance with the principles of audit activity standardization can be divided into:

- $\quad$ procedural indicators, i.e. compulsory ones. For example, the number of contradictions identified in the texts of standards at the development stage, amount of time needed to provide the recipient with information, the number of standards with the structure different from the generally established one;

- regulatory indicators, which regulate the activity through average values or divergence limits. For example, costs for organizing the work on audit activity standardization;

- instruction and information indicators, which allow to take into account specific work environment and positive experience. For example, the number of the developed standards fully complying with international standards, share of justified contradictions between the developed and international standards in the total number of contradictions of that kind, average number of proposed innovative changes.

All the above-mentioned indicators are individual, i.e. they characterize only one aspect of a given object of evaluation. Based on those individual indicators, it is impossible to judge about the quality of development of standards regarding compliance with the principles of audit activity standardization.

As mentioned earlier, the proposed principles are not just a set but a system which acquires a new quality compliance with all the principles leads to quality standards meeting the needs of their users. That calls for a single indicator which would allow to estimate the state of the system of standards of audit activity standardization. In our opinion, that role can be performed by a rating. 
Rating is a cardinal or ordinal indicator, which reflects the expert's (group of experts') opinion about the significance of an object or action generated by using a certain method and usually expressed in points (Zavarikhin, Paramonov, 2012).

A possible method for calculating the rating of the state of the system of principles of audit activity standardization is described below. To calculate the rating, the above-mentioned indicators of detailed evaluation over different periods are used. For each indicator, its optimal value is determined and set equal to 1 . By using the values of that indicator over other periods, the share of the indicator in its optimal value is calculated. By summing up the ratings for each indicator over a relevant period, the total rating of the period is calculated.

The matrix of rating evaluation in its general form is shown in Table 7.

Table 7 - Matrix of rating evaluation (Slobodnyak, 2012)

\begin{tabular}{ccccc} 
Indicator & \multicolumn{5}{c}{ Periods } & $\mathrm{n}$ & Optimal value \\
& $\mathrm{X}_{11}$ & $\mathrm{X}_{12}$ & $\mathrm{X}_{1 \mathrm{n}}$ & $\mathrm{X}_{1 \mathrm{opt}}$ \\
1 & $\mathrm{R}_{11}$ & $\mathrm{R}_{12}$ & $\mathrm{R}_{1 \mathrm{n}}$ & \\
& $\mathrm{X}_{21}$ & $\mathrm{X}_{22}$ & $\mathrm{X}_{2 \mathrm{n}}$ & $\mathrm{X}_{2 \text { opt }}$ \\
2 & $\mathrm{R}_{21}$ & $\mathrm{R}_{22}$ & $\mathrm{R}_{2 n}$ & \\
$\mathrm{~m}$ & $\mathrm{X}_{\mathrm{m} 1}$ & $\mathrm{X}_{\mathrm{m} 2}$ & $\mathrm{X}_{\mathrm{mn}}$ & $\mathrm{X}_{\mathrm{mopt}}$ \\
Total & $\mathrm{R}_{\mathrm{m} 1}$ & $\mathrm{R}_{\mathrm{m} 2}$ & $\mathrm{R}_{\mathrm{mn}}$ & \\
Place & Total $\mathrm{R}_{1}$ & Total $\mathrm{R}_{2}$ & Total $\mathrm{R}_{\mathrm{n}}$ & \\
& & & &
\end{tabular}

Thus, the proposed integral evaluation will allow to get general idea of the state of the system of principles of audit activity standardization, while changes of that evaluation are determined through the individual indicators. It should be noted that rating and detailed evaluation, can be performed in the interests of developers of audit activity standards to order to make the necessary changes into the standardization process, from one hand, and used by supervisors as a monitoring tool, on the other hand.

The proposed rating and detailed evaluation, can be performed in the interests of developers of audit activity standards to order to make the necessary changes into the standardization process, from one hand, and used by supervisory agencies as a tool for monitoring the effectiveness of audit activity standardization.

\section{Conclusion}

During the research, the authors attempted to develop the conceptual basis for development of audit activity standards. The research covered the following main areas: principles and methods of standardization, identification of objects of standardization and their classification, classification of audit activity standards and evaluation of compliance with the principles of audit activity standardization as quality criteria for the developed standards. It should be noted that the research did not cover such important elements of the system of audit activity standardization, as subjects of standardization and stages of standard development, which are the objects of further research.

\section{References}

Belobragin V.Ya. (2011). O nauchno-metodicheskikh osnovakh standartizatsii. Tezisy doklada na "kruglom stole" organizuemom Rosstandartom I redaktsiei zhurnala "Standarty I kachestvo" [On the scientific-methodical bases of standardization. Theses of the report on «round table», organized by RosStandart and editors of the magazine «Standards and quality»] Retrieved from http://webportalsrv.gost.ru/portal/GostNews.nsf/acaf7051ec840948c22571290059c78f/c2d035f5d245aea4c32575e8002ee115/\$F ILE/2011-11-23-tes.pdf [in Russian].

Bernowski Yu.N. (2012). Zakon "O standartizatsii": vnosim predlozheniia [The law "About standardization": suggestions]. Standarty $i$ kachestvo - Standards and quality 9, 29 [in Russian].

Bulyga R.P. (2012). Innovatsii sovremennogo audita: audit effiektivnosti biznes-protsesov [Innovations of modern audit: audit the effectiveness of business processes]. Audtor - The Auditor, 3, 16[in Russian].

Burtsev V.V.(2000). K voprosu o standartizatsii gosudarstvennogo controlia [To the question of standardization of the state financial control]. Menedzhment v Rossii I zarubezhom - Management in Russia and abroad, 1. Retrieved from http://www.cfin.ru/press/ management/2000-1/07.shtml [in Russian].

Chaya V.T. (2012). Kachestvo audita: zadachi I resheniia [Quality of audit: challenges and solutions]. Auditorskie vedomosti - Auditor's 
journal, 11,46 .

Chernova M.V. (2011). Problemy sovremennogo audita [Problems of modern audit]. Mezhdunarodnyi bukhgalterskii uchet - International accounting, 43, 37.

Guttsait E.M. (2002). Metodologicheskie problemy audita [Methodological problems of auditing]. Auditorskie vedomosti - Auditor's journal, $10,8$.

Korotkov E.M. (2000). Issledovanie sistem upravleniia [Research of management systems]. Moskva Izdatelsko-konsaltingovaia kompaniia "DeKA" - Moscow, "DeKA" publishing and consulting company. Retrieved from http://www.bibliotekar.ru/sistemaupravleniya/index.htm.

Kostyleva Y.J. \& Kostylev, V.A. (2005). Oformlenie osnovnykh dokumentov auditora [Design of the main documents of auditor]. Auditorskie vedomosti - Auditor's journal, 8, 25-26.

Massarydina V.F. (2012). O primenenii mezhdunarodnykh standartov $\mathrm{v}$ otechestvennom bukhgalterskom uchete I audite [On the application of international standards in the national accounting and auditing]. Auditor - The Auditor, 9, 37.

Melnik M.V.\& Kogdenko V.G. (2005). Metodologiia audita: pazvitie novykh napravlenii [Audit methodology: development of new directions]. Auditorskie vedomosti - Auditor's journal, 10, 5.

Nikolaeva M.A. \& Kartashova L.V. (2010). Standartizatsiia, metrologiia I podtvergdenie sootvetstviia [Standardization, metrology and conformity]. Moscow ID «FORUM»: INFRA-M.

Novikov A.M.\& Novikov D.A. (2007). Metodologiia [Methodology]. Moscow: SINTEG.

Ozhegov S.I. (1987) Slovar' russkogo iazyka [Dictionary of Russian]. Manual edited by N.Yu. Shvedova. Moscow, Russkii iazyk Publ.

Pankova S.V. \& Pasechnekova L.V. (2013). Sushchnost audita marketinga I protsedury ego provedeniia [The essence of the marketing audit and the procedure of its holding]. Mezhdunarodnyi bukhgalterskii uchet - International accounting, 7, 22.

Petrova V.I. (2009). Kontseptsiia audita: osnovnye elementy [The concept of audit: the main elements]. Auditorskie vedomosti - Auditor's journal, $12,8$.

Podolsky V.I. (2010). Klassifikatsiia standartov auditorskoi deiatelnosti [Classification of auditing standards]. Auditorskie vedomosti Auditor's journal, 6, 4-11.

Postyka V.M. \& Filippov V.V. O sistemnosti v standartizatsii I sistemoobrazuiushchikh standartah [The systematic approach to standardization and backbone standards]. Retrieved from http://quality.eup.ru/STANDART/sysstand.htm.

Sheremet A.D. (2007). Auditorskaia deiatel'nost' i analiz effektivnosti biznesa [Auditing activities and the analysis of business efficiency]. Auditorskie vedomosti - Auditor's journal, 5, 7.

Slobodniak I.A. (2012) Analiz integral'noi dinamiki finansovogo sostoianiia organizatsii i rezul'tatov ee finansovo-khoziaistvennoi deiatel'nosti s ispol'zovaniem reitingovoi otsenki [Analysis of integral dynamics of the financial state of the company and results of its financial and economic activity with the use of ratings]. Finansovyi vestnik: finansy, nalogi, strakhovanie, bukhgalterskii uchet Financial herald: finances, taxes, insurance, bookkeeping calculation, 11, 3-14.

Surkova I.B. (2012). Kontseptsiia auditorskoi deiatel'nosti kak mnogourovnevoi sistemy [Concept of auditing as a multilevel system]. Auditor - The Auditor, 5, 21-23.

Zavarikhin N.M. \& Paramonov A.V. (2012) O reitingakh i renkingakh auditorskikh kompanii v Rossii [About the ratings and rankings of the audit companies in Russia]. Auditor - The Auditor, 3, 27.

Zevaikina A.N. (2010) Poniatie I sootnoshenie audita I soputstvuiushchikh auditu uslug [The concept and the ratio of audit and related services]. Auditor - The Auditor, 5, 36-37.

Zharylgasova B.T. (2007) Obshchie rekomendatsii po razrabotke vnutrifirmennykh standartov auditorskoi deiatelnosti [General recommendations for the development of internal auditing standards]. Auditorskie vedomosti - Auditor's journal, 12, 19, 22.

Zhminko S.I. \& Baklanova P.B. (2012) Printsipy I poriadok razrabotki federalnykh standartov auditorskoi deiatelnosti [The principles and the procedure of the development of Federal standards of auditing activity]. Mezhdunarodnyi bukhgalterskii uchet - International accounting, 32, 47. 